\title{
Analisis Stabilitas Transien dengan Perbaikan Menggunakan Power System Stabilizer pada PT. Pertamina (Persero) Refinery Unit III Plaju, Sumatera Selatan
}

Azman Fadhli R ${ }^{1}$, Maison ${ }^{1}$, dan Dasrinal Tessal ${ }^{1}$

Teknik Elektro, Fakultas Teknik, Universitas Jambi, Jambi, Indonesia

Email: azmanfadhlir@gmail.com, maison@unja.ac.id, dasrinaltessal@unja.ac.id

Info Artikel

Diterima: 16 Maret 2020

Disetujui: 10 Agustus 2020

Dipublikasikan: 31 Agustus 2020

\section{Alamat Korespondensi:} azmanfadhlir@gmail.com

Copyright $@ 2020$ Jurnal Engineering

This work is licensed under the Creative Commons Attribution International License ( CC BY $4.0)$.

\begin{abstract}
Abstrak:
Kilang polypropylene Refinery Unit III merupakan kilang bijih plastik terbesar kedua milik Pertamina setelah kilang polypropylene Refinery Unit IV Balongan dan merupakan kilang bijih plastik yang pertama kali dibangun oleh Pertamina. Kilang ini membutuhkan kontinuitas penyediaan tenaga listrik yang baik. Namun, sistem kelistrikan pada umumnya tidak terlepas dari gangguan, baik gangguan besar maupun kecil, dimana gangguan ini dapat bersifat sementara atau tetap. Sehingga perlu dilakukan analisis stabilitas transien untuk mengetahui kehandalan sistem untuk melihat reaksi terhadap gangguan yang terjadi. Dalam penelitian ini, analisis yang dilakukan meliputi kestabilan transien akibat gangguan 3 fasa dan gangguan 1 fasa menggunakan metode kualitatif dengan perangkat lunak simulasi ETAP 12.6 dengan didapatkan nilai rata - rata frekuensi $=50,45 \mathrm{~Hz}$, Tegangan $=12,67 \mathrm{kV}$, Sudut Rotor $= \pm 3,1^{\circ}$. Sedangkan dengan upaya perbaikan menggunakan Power System Stabilizer (PSS) nilai rata - rata frekuensi= $50,44 \mathrm{~Hz}$, Tegangan $=12,05 \mathrm{kV}$, Sudut Rotor $= \pm 2,3^{\circ}$. Hasil penelitian menunjukan bahwa sebelum pemasangan PSS, waktu peralihan sistem setelah terjadi gangguan yaitu tegangan 22,1 detik dan sudut tegangan 33,4 detik, dan setelah pemasangan PSS, waktu peralihan lebih baik yaitu tegangan 17,4 detik dan sudut tegangan 28,9 detik.
\end{abstract}

Kata Kunci : Stabilitas Transien, Power System Stabilizer, ETAP

\section{Pendahuluan}

Indonesia merupakan negara kaya akan sumber daya alam, terutama pada sumber daya minyak dan gas bumi . Pada masa sekarang ini permintaan akan minyak dan gas bumi sebesar 2 juta Barel Oil Equivalent (BOE) per hari sedangkan permintaan minyak dan gas bumi diluar negeri sebesar 7,43 juta BOE per hari sehingga dibutuhkan pengolahan minyak dan gas bumi secara tepat dan efisien. Dalam hal ini, salah satu perusahaan minyak yang cukup berperan dalam mengatasi kebutuhan minyak dan gas bumi di Indonesia yaitu PT. Pertamina (Persero) Refinery Unit (RU) III Plaju, Sumatera Selatan. (Birol, 2019)

PT. Pertamina (Persero) RU III Plaju merupakan salah satu dari 6 unit operasi pengolahan yang masih aktif di Indonesia dan mempunyai kapasitas sebesar 126,2 thousand barrels per stream day (MBSD) untuk memenuhi kebutuhan minyak bumi. Perusahaan ini terdapat unit-unit crude distilling unit (CDU), high 
vacuum unit (HVU), fluid catalytic cracking unit (FCCU), Polypropylene, Alkilasi, dan Polymerisasi sebagai pendukung utama untuk menghasilkan produk seperti bahan bakar minyak (BBM), bahan bakar khusus (BBK), liquid petroleum gas (LPG), Petrokimia, dan non BBM (NBBM). Dalam proses penyediaan tenaga listrik, PT. Pertamina (Persero) RU III Plaju berupaya mandiri untuk mengelola sumber pembangkitan tenaga listrik. Perusahaan ini menggunakan Pembangkit Listrik Tenaga Gas (PLTG) berkapasitas $31 \mathrm{MW}$ yang dialirkan ke seluruh kilang area plaju dan sungai gerong. (Marsudi, 2011) Sistem kelistrikan pada umumnya tidak luput dari seringnya terjadi gangguan, maka dari itu perlu dilakukan simulasi menggunakan ETAP 12.6 untuk melihat gangguan yang terjadi dan menganalisa aliran daya serta memperbaiki kestabilan dengan melihat perbandingan sebelum dan setelah menggunakan PSS.

\section{Landasan Teori}

\subsection{Persamaan Ayunan}

Mesin yang mengalami gangguan atau perubahan kondisi dalam pengoperasian akan menyebabkan energinya berayun, dan mempunyai kemungkinan kembali stabil setelah gangguan hilang, atau tetap berayun dan tidak mungkin lagi kembali stabil sehingga perlu dilakukan pemisahan dari sistem. Jika generator sinkron menerima torsi mekanik sebesar Tm maka akan menimbulkan torsi elektrik sebesar Te, dan dengan mengabaikan rugi-rugi energi yang terjadi maka didapatkan persamaan sebagai berikut (Stevenson, 1955).

$$
T_{m}-T_{e}
$$

Jika Ta adalah selisih anatara torka mekanik dengan torka elektrik pada mesin maka Ta didefinisikan sebagai torka percepatan atau pelambatan dari mesin dengan persamaan

$$
T_{a}=T_{m}-T_{e}
$$

Jika mesin memiliki momen inersia atau momen kelembaman dalam merespons perubahan maka kondisi yang terjadi sebesar J dan dengan mengabaikan gaya gesekan serta redaman maka torka percepatan / perlambanan mesin dapat dirumuskan

$$
J \frac{d^{2} \theta_{m}}{d t^{2}}=T_{a}=T_{m}-T_{e}
$$

Dimana $\theta m$ besar sudut perputaran mesin. Jika $W s m$ kecepatan sudut yang tetap maka,

$$
\theta_{m}=w_{s m} t+\delta_{m}
$$

Dimana $\delta m$ adalah posisi baling-baling sebelum gangguan pada saat $\mathrm{t}=0$, maka kecepatan sudut rotor

$$
\omega_{m}=\frac{d \theta_{m}}{d t}=\omega_{m s}+\frac{d \delta_{m}}{d t} .
$$

Dan percepatan sudut rotor adalah

$$
\frac{d^{2} \theta_{m}}{d t^{2}}=\frac{d^{2} \delta_{m}}{d t^{2}}
$$

Substitusi persamaan 6 dengan 3 diperoleh persamaan

$$
J \frac{d^{2} \delta_{m}}{d t^{2}}=T_{m}-T_{e}
$$

Dan dengan mengalihkan dengan $\omega_{m}$, mengakibatkan

$$
J \omega_{m} \frac{d^{2} \delta_{m}}{d t^{2}}=\omega_{m} T_{m}-\omega_{m} T_{e}
$$


Daya adalah perkalian torka dan besar sudut perputarannya maka didapat persamaan sebagai berikut

$$
J \omega_{m} \frac{d^{2} \delta_{m}}{d t^{2}}=P_{m}-P_{e}
$$

Persamaan ayunan mesin menjadi

$$
\frac{2}{P} M \frac{d^{2} \delta}{d t^{2}}=P_{m}-P_{e}
$$

atau dapat ditulis menjadi

$$
\frac{22 W_{k} d^{2} \delta}{p \omega_{m} S_{B} d t^{2}}=\frac{P_{m}}{S_{B}}-\frac{P_{e}}{S_{B}}
$$

Sebagai konstanta II tetap dan dengan menggunakan satuan perunit maka didapat

$$
\frac{22 H d^{2} \delta}{p \omega_{s m} d t^{2}}=P_{m(p u)}-P_{e(p u)}
$$

dimana $P_{m(p u)}$ dan $P_{e(p u)}$ adalah gaya mekanis per-unit dan daya listrik. Kecepatan sudut elektrik dihubungkan dengan kecepatan sudut mekanis oleh persamaan

$$
\omega_{s m}=\left(\frac{2}{p}\right) \omega_{s}
$$

dalam kaitan dengan kecepatan sudut elektrik adalah

$$
\frac{2 H d^{2} \delta}{\omega_{s} d t^{2}}=P_{m(p u)}-P_{e(p u)}
$$

Jika kecepatan dinyatakan dalam frekuensi maka didapat

$$
\frac{H d^{2} \delta}{\pi f 0 d t^{2}}=P_{m}-P_{e}
$$

Dimana $\delta$ adalah radian elektrik dalam elektrik, maka didapat persamaan ayunan adalah

$$
\frac{H d^{2} \delta}{180 f 0 d t^{2}}=P_{m}-P_{e}
$$

\subsection{Kestabilan Sistem Tenaga Listrik}

Kestabilan didefinisikan sebagai kemampuan suatu sistem tenaga listrik untuk kembali beroperasi pada kondisi normal dititik keseimbangan dalam kondisi saat dan setelah mengalami gangguan sehingga sistem tetap utuh. Sistem tenaga listrik merupakan sistem nonlinier dikarenakan beroperasi pada lingkungan yang terus berubah. Untuk menjaga operasi sistem tenaga listrik agar dapat berjalan dengan baik, maka kestabilan dari sistem perlu diperhatikan. Kestabilan sistem tenaga listrik dipengaruhi oleh beberapa hal dikarenakan variasi beban yang dinamis (berubah - ubah).

Analisis kestabilan pada umumnya digolongkan kedalam tiga jenis, tergantung pada sifat dan besarnya gangguan yaitu Kestabilan Keadaan Tetap (Steady State Stability), Kestabilan Dinamis (Dynamic Stability), Kestabilan Transien (Transien Stability). Dengan mempertimbangkan beberapa hal seperti ukuran gangguan, permodelan dan analisis gangguan yang spesifik, waktu saat terjadi gangguan, serta parameter sistem yang paling berpengaruh.

\subsection{Power System Stabilizer (PSS)}

Kestabilan dinamik dalam sistem daya listrik ditentukan oleh kemampuan berbagai komponen pembangkit dalam pemberian transfer respons terhadap perubahan beban yang terjadi. Perubahan beban yang terjadi secara tiba - tiba dan periodik tidak dapat direspon dengan baik oleh generator sehingga dapat 
mempengaruhi kestabilan dinamik sistem. Respons yang kurang baik dapat menimbulkan osilasi frekuensi dalam periode yang sama. Hal itu akan mengakibatkan pengurangan kekuatan transfer daya yang dapat diatasi menggunakan peralatan tambahan yang disebut Power System Stabilizer (PSS).

\subsubsection{Konsep Dasar PSS}

PSS merupakan peralatan yang menghasilkan sinyal kontrol untuk diumpankan pad sistem eksitasi. Namun pada pendekatan yang lebih baru, sinyal kontrol yang keluar dari PSS diumpankan juga ke sisi turbin. Fungsi dasar PSS adalah menambah batas kestabilan dengan mengatur eksitasi generator untuk memberi redaman terhadap osilasi rotor mesin sinkron. Osilasi itu terjadi dengan simpangan $0,2-0,5 \mathrm{~Hz}$ dan tidak kemampuan transfer daya. Untuk memberikan peredaman, PSS harus menghasilkan komponen torsi elektrik pada mesin yang sefasa.

\subsubsection{Komponen PSS}

Implementasi sebuah PSS pada sistem daya yang disambungkan melalui $\Delta=V p$ ke port stabilizer adalah seperti yang ditunjukkan pada Gambar 1.

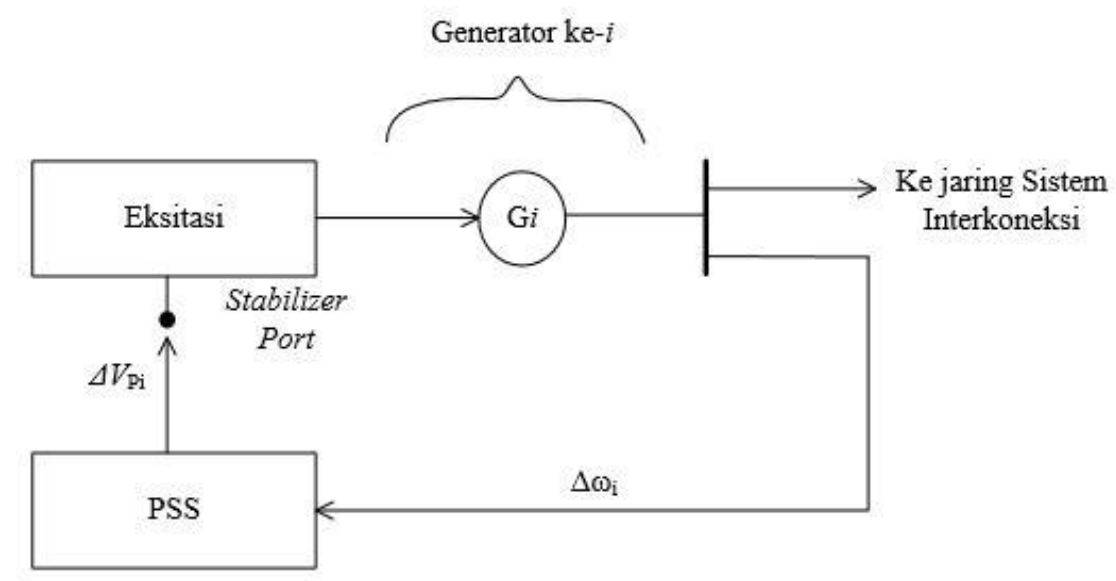

Gambar 1 Sebuah sistem PSS pada generator ke - i

Model PSS terdiri dari beberapa blok seperti disajikan pada Gambar 2.

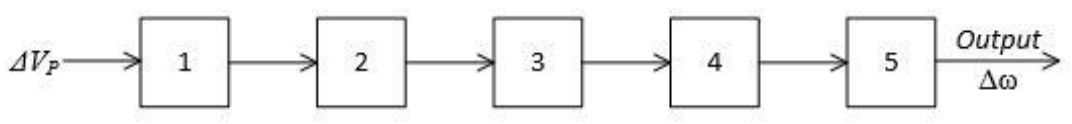

\section{Metodologi Penelitian}

\section{Gambar 2 Komponen PSS}

\subsection{Struktur Sistem}

PT. Pertamina RU III Plaju memiliki 3 pusat pembangkit tenaga listrik yaitu : Power Station I (PS I) yang terletak di Plaju, Power Station II (PS II) yang terletak di Plaju, dan Power Station III (PS III) yang terletak di Sungai Gerong. Akan tetapi pada saat ini pusat pembangkit tenaga listrik yang dioperasikan untuk menunjang pasokan kebutuhan listrik di PT. Pertamina RU III Plaju hanya PS II , sedangkan PS I dan PS III sudah tidak dioperasikan lagi. 


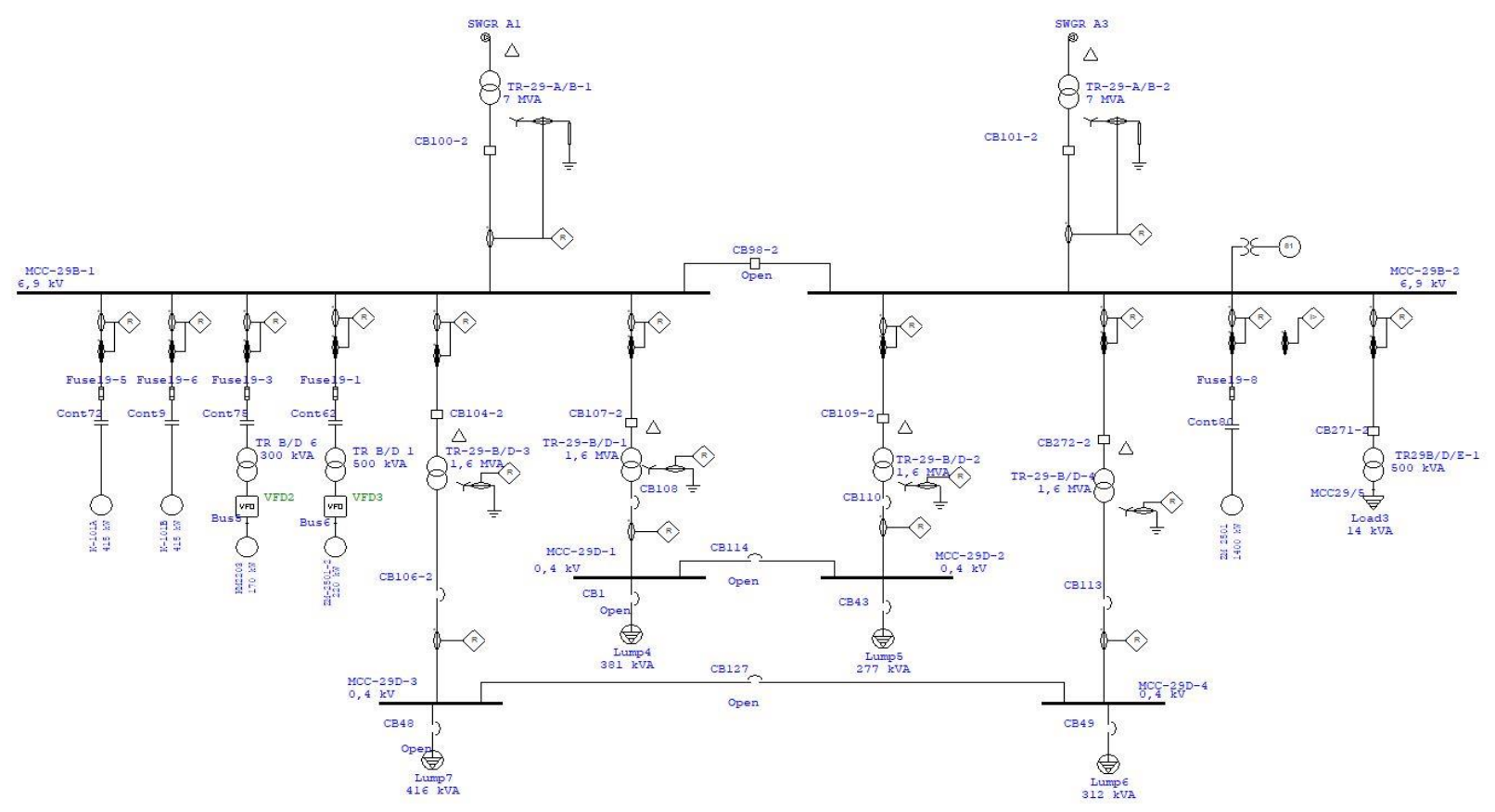

Gambar 3 Diagram Satu Garis Kilang Polypropylene

(PS II) memiliki 5 unit pembangkit, yang terdiri dari 3 unit Gas Turbine Generator (GTG) dengan kapasitas rating sama masing masing sebesar 31 MW yaitu GTG 2015-UA, GTG 2015-UB, GTG 2015-UC dengan kondisi normal 2 unit untuk GTG 2015-UA dan GTG 2015-UB beroperasi dan 1 unit GTG 2015-UC dalam keadaan tidak beroperasi, 1 unit Steam Turbine Generator (STG 2017-U) berkapasitas 3,2 MW digunakan sebagai supply cadangan apabila dalam keadaan darurat jika terjadi gangguan / kerusakan pada 3 unit GTG utama dan 1 unit Emergency Diesel Generator (EDG 2016-U) berkapasitas $750 \mathrm{~kW}$ juga sebagai secure system yang berfungsi sebagai penggerak motor Auxilarys meliputi penerangan, kontrol motor-motor, Uninterruptible Power Supply(UPS) dan kebutuhan lokal di kilang. (Defariza, 2011)

Tabel 1 Data Pembangkit di PT. Pertamina (Persero) RU III

\begin{tabular}{ccccccc}
\hline No & ID & Tipe & $\begin{array}{c}\text { Ruang } \\
\text { Daya } \\
(\mathbf{M W})\end{array}$ & $\begin{array}{c}\text { Rating } \\
\text { Tegangan } \\
(\mathbf{k V})\end{array}$ & $\begin{array}{c}\text { Power } \\
\text { Factor } \\
\mathbf{( \% )}\end{array}$ & $\begin{array}{c}\text { Kecepatan } \\
\text { Sinkron } \\
(\mathbf{r p m})\end{array}$ \\
\hline $\mathbf{1}$ & $2015-\mathrm{UA}$ & GTG & 31 & 12 & 80 & 3000 \\
\hline $\mathbf{2}$ & $2015-\mathrm{UB}$ & GTG & 31 & 12 & 80 & 3000 \\
\hline $\mathbf{3}$ & $2015-\mathrm{UC}$ & GTG & 31 & 12 & 80 & 3000 \\
\hline $\mathbf{4}$ & $2016-\mathrm{U}$ & STG & 3,2 & 6,9 & 80 & 1500 \\
\hline $\mathbf{5}$ & $2017-\mathrm{U}$ & EDG & 0,75 & 0,4 & 80 & 750 \\
\hline
\end{tabular}

Tabel 2 Data Beban GTG 2015 - UA/UB/UC

\begin{tabular}{clc}
\hline No. & \multicolumn{1}{c}{ Load Type } & Load (MW) \\
\hline 1. & Kilang BBM Plaju & 5,00 \\
\hline 2. & Kilang BBM Sungai Gerong & 6,00 \\
\hline 3. & Kilang TA \& PTA & 0 \\
\hline 4. & Kilang Polypropylene & 2,30 \\
\hline 5. & Off-sites \& Utilities & 7,90 \\
\hline 6. & Offices & 1,10 \\
\hline 7. & Public Facilities & 2,00 \\
\hline & Total & 24,00 \\
\hline
\end{tabular}


Sistem jaringan distribusi tenaga listrik yang digunakan di PT. Pertamina Refinery Unit III Plaju adalah sistem jaringan radial ganda dan sistem ring. Sistem radial ganda ini terdiri dari sepasang sumber yang masuk atau sepasang trafo atau sepasang feeder dari substation lain yang memiliki tipe dan kapasitas yang sama serta terhubung dengan dua substation yang identik juga, dimana dua substataion yang identik tersebut terhubung dengan sebuah Normally Open The Circuit Breaker ( Bus Coupler atau Automatic Transfer Switch ) satu dengan yang lainnya. Sistem ini sangat baik dalam pelayanan terhadap beban yang membutuhkan kontinuitas yang tinggi sebab apabila salah satu sumber mengalami gangguan, maka supply daya dapat dilayani dari sumber yang lain dengan menghubungkan Bus Coupler. Oleh karena itu, sistem ini dipakai pada substation untuk melayani kebutuhan listrik di kilang.

\subsection{Flowchart Penelitian}

Objek dari penelitian ini adalah mensimulasikan perbandingan sebelum dan setelah menggunakan PSS pada sistem menggunakan perangkat lunak ETAP 12.6 dengan memberikan gangguan 1 fasa dan gangguan 3 fasa.

\subsection{Waktu dan Tempat Penelitian}

Penelitian dilakukan selama 30 hari di PT. Pertamina RU III Sumatera Selatan pada bulan Juli Agustus 2019.

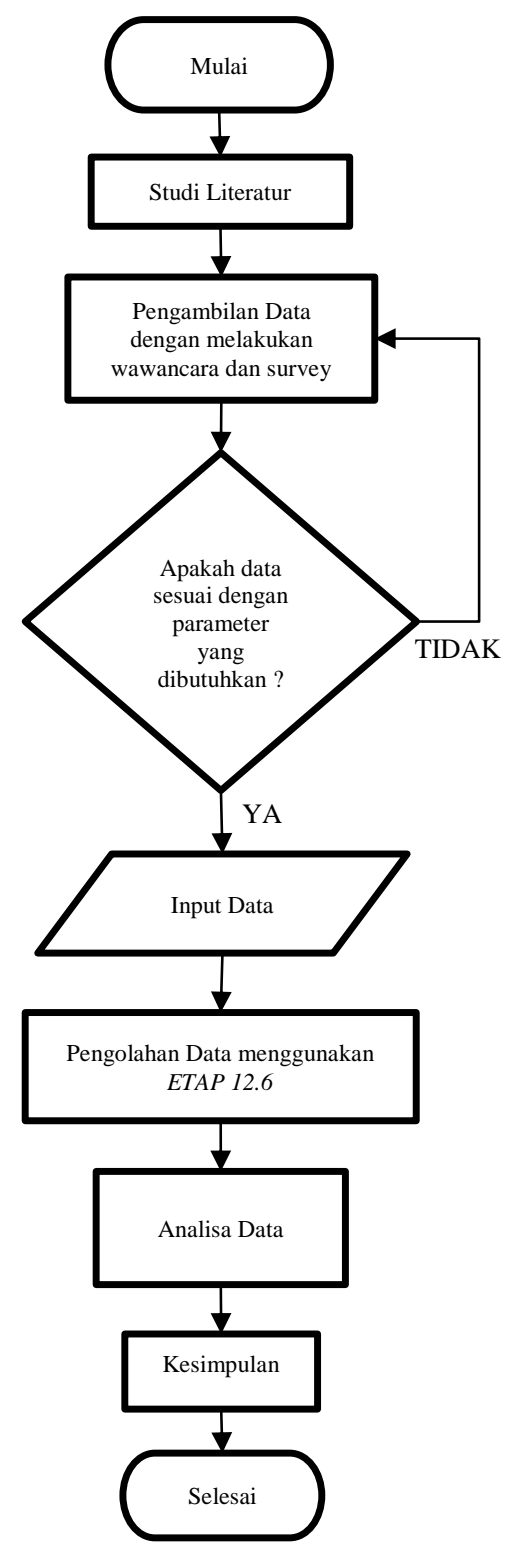

Gambar 4 Flowchart Penelitian 


\section{Hasil Penelitian dan Pembahasan}

\subsection{Permodelan Sistem}

Single line diagram PT. Pertamina RU III Plaju dimodelkan melalui software ETAP 12.6 dengan menggunakan data-data keluaran dan data peralatan yang digunakan di PT. Pertamina RU III Plaju. Kemudian dilakukan simulasi untuk menganalisis kestabilan sistem ketika mengalami gangguan besar pada unit kilang polypropylene. Pengujian sistem kelistrikan di PT. Pertamina RU III Plaju terhadap gangguan besar bertujuan untuk mengetahui respon sistem terhadap gangguan-gangguan yang mungkin terjadi. Oleh karena itu, perlu dilakukan analisis sistem dengan cara memberikan gangguan pada sistem kelistrikan. Studi kasus yang akan dibahas pada penelitian ini dapat dilihat pada Tabel 3.

Tabel 3 Tabel Studi Kasus

\begin{tabular}{|c|c|c|c|c|c|}
\hline No & Generator & $\begin{array}{c}\text { Tipe } \\
\text { Operasi }\end{array}$ & $\begin{array}{c}\text { Jenis } \\
\text { Gangguan }\end{array}$ & $\begin{array}{c}\text { Lokasi } \\
\text { Gangguan }\end{array}$ & $\begin{array}{c}\text { Keteranga } \\
\mathbf{n}\end{array}$ \\
\hline 1 & GTG 2015-UA & Slack Bus & 3 Phase Fault & MCC29B-1 & - \\
\hline & & & 1 Phase Fault & MCC29B-2 & \\
\hline 2 & GTG 2015-UB & PV Bus & & & - \\
\hline 3 & GTG 2015-UC & PV Bus & Stand By & - & $\begin{array}{c}\text { Tidak } \\
\text { beroperasi, } \\
\text { sebagai } \\
\text { supply } \\
\text { cadangan }\end{array}$ \\
\hline
\end{tabular}

4.2. Hasil Simulasi Aliran Daya

Data PSS

Pada bagian ini digunakan referensi data penelitian terdahulu untuk nilai tiap variabel pada pengaturan PSS, untuk mencapai kestabilan transien sistem tenaga listrik yang baik setelah diberikan gangguan.

Tabel 4 Data Power System Stabilizer (PSS=2A)

\begin{tabular}{|c|c|c|c|c|c|c|c|c|c|}
\hline KS1 & $\mathrm{KS} 2$ & KS3 & $\mathrm{V}_{\text {STMAX }}$ & $\mathrm{V}_{\text {STMIN }}$ & VTMin & TDR & $\mathrm{Tw} 1=\mathrm{Tw} 2=\mathrm{Tw} 3=\mathrm{Tw}$ & $\mathbf{N}$ & M \\
\hline 20 & 0,001 & 1 & 0,2 & $-0,066$ & 0 & 0,2 & 10 & 4 & 2 \\
\hline & $\mathrm{T}_{1}$ & & $\mathrm{~T}_{2}$ & $\mathrm{~T}_{3}$ & $\mathrm{~T}_{4}$ & $\mathrm{~T}_{6}-\mathrm{T}_{7}$ & $\mathrm{~T}_{8}$ & & \\
\hline & 0,16 & & 02 & 0,16 & 0,02 & 0 & 0,3 & & \\
\hline
\end{tabular}

(Dewantara, 2016)

Sementara nilai yang digunakan untuk simulasi kali ini berdasarkan metode trial and error dilihat dari beberapa percobaan berdasarkan batas normal dari tegangan, sudut rotor dan frekuensi sesuai standar yang digunakan.

Tabel 5 Data Power System Stabilizer

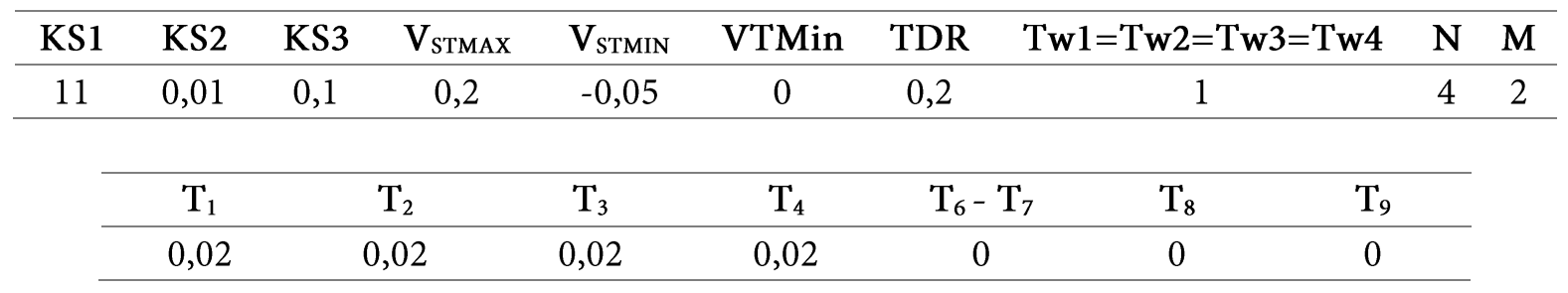


Kondisi 1

Kondisi 1 adalah saat gangguan 3 fasa terjadi di bagian MCC29B1 dan berpengaruh terhadap GTG 2015-UA dan 2015-UB. Pada Gambar 5 dapat dilihat bahwa terjadi perubahan tegangan ketika sebelum gangguan dan setelah pengaktifan PSS2A. Gangguan 3 fasa terjadi pada waktu $(t)=12,001$. Kemudian, tegangan pada bus collapse hingga titik $10,46 \mathrm{kV}$ pada waktu $(\mathrm{t}) 12,301$ dengan frekuensi $49,81 \mathrm{~Hz}$. Kemudian dilakukan pembukaan CB 100-2 untuk mencoba kembali ke titik kestabilan dalam waktu $(\mathrm{t})=$ 4,6 detik.
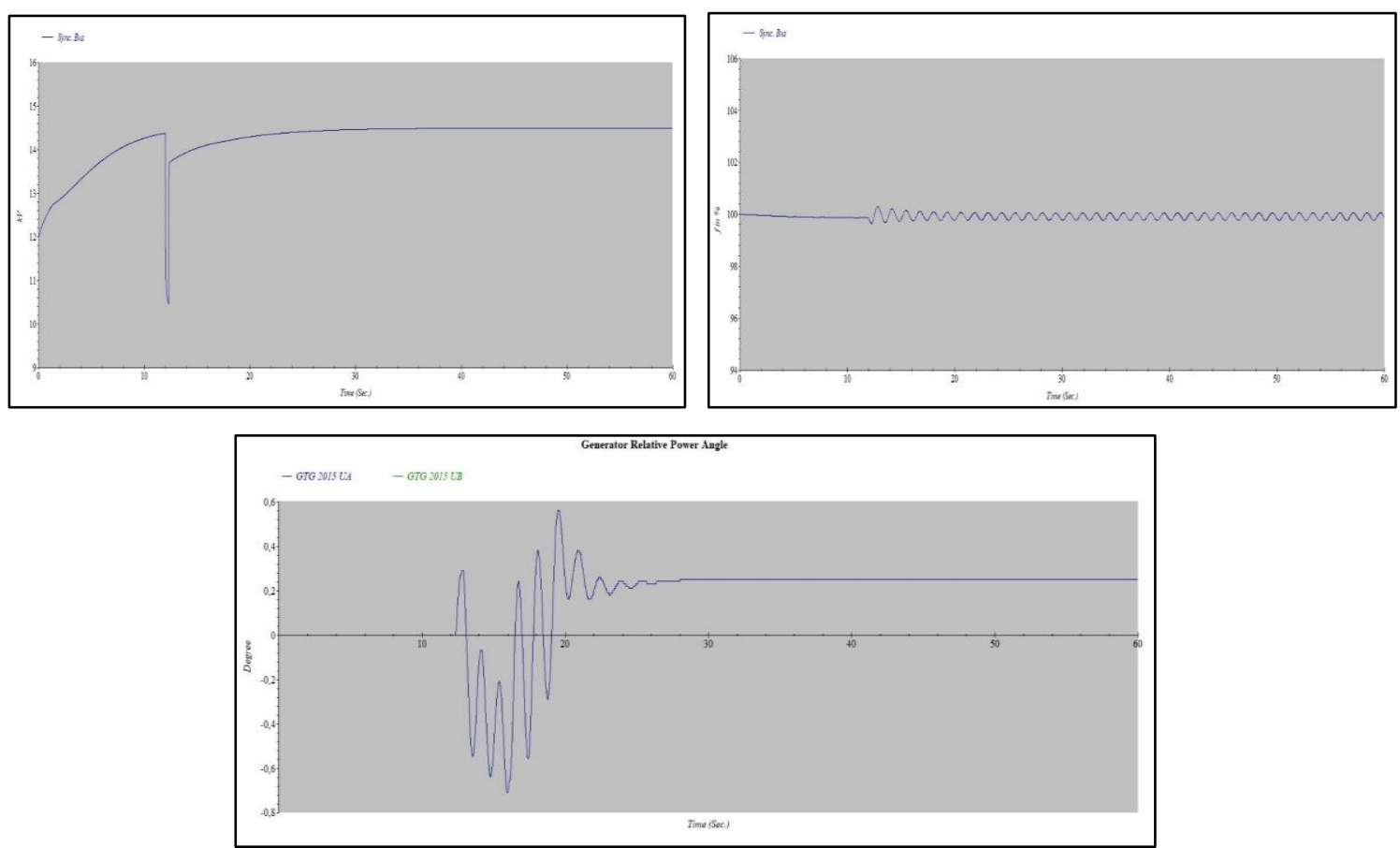

Gambar 5 Respon tegangan, frekuensi dan sudut rotor generator saat gangguan 3 fasa pada MCC29B1 setelah pengaktifan PSS

Gambar 6 adalah grafik tegangan bus pada MCC29B1 yang mengalami gangguan 1 fasa setelah pengaktifan PSS. tegangan mencoba naik dengan rise time $(\mathrm{t})=10$ detik untuk mencapai posisi kestabilan baru dengan nilai tegangan 14,489 kV. Kondisi bus MCC29B1 mengalami gangguan 1 fasa. Untuk bus voltage angle pada saat setelah pengaktifan PSS terjadi penurunan sudut tegangan saat terjadi gangguan 1 fasa yaitu $0,1^{\circ}$ selama selang waktu $(\mathrm{t})=4,56$ detik sebelum kemudian kembali keadaan kestabilan.

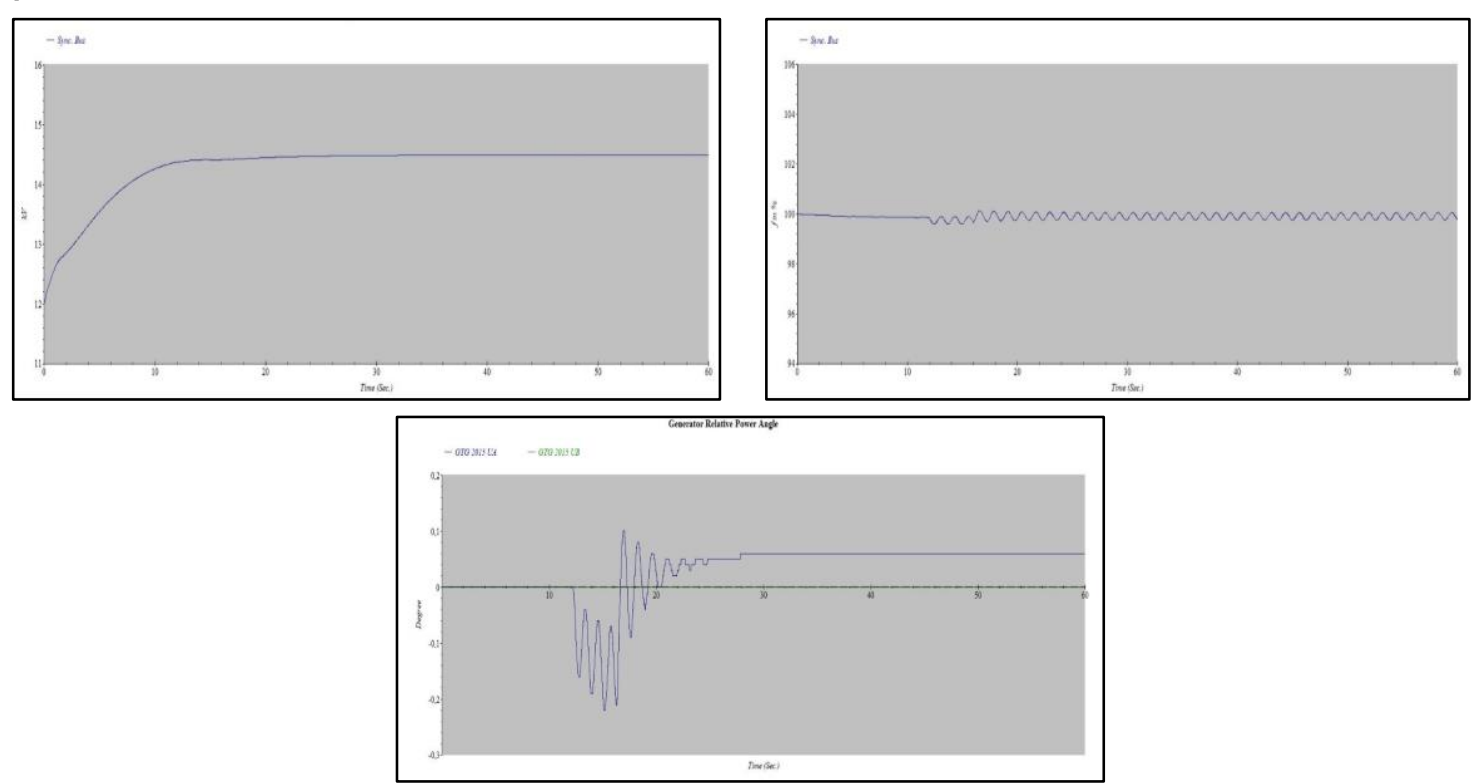

Gambar 6 Respon tegangan, frekuensi, dan sudut rotor generator saat gangguan 1 fasa pada MCC29B1 setelah pengaktifan PSS 


\section{Kondisi 2}

Kondisi 2 adalah saat gangguan satu fasa terjadi dibagian MCC29B2 dan berpengaruh terhadap GTG 2015-UA dan 2015-UB. Pada Gambar 7 dapat dilihat bahwa terjadi perubahan tegangan dan sudut tegangan saat terjadi gangguan pada waktu $(t)=12,001$. Kemudian terjadi penurunan tegangan hingga mengalami titik terendah pada waktu $(t)=12,511$ dengan nilai tegangan $10,153 \mathrm{kV}$ dengan frekuensi 49,94 Hz. Kemudian mencoba ke posisi kestabilan dengan rentang waktu $(t)=8,2$ detik.

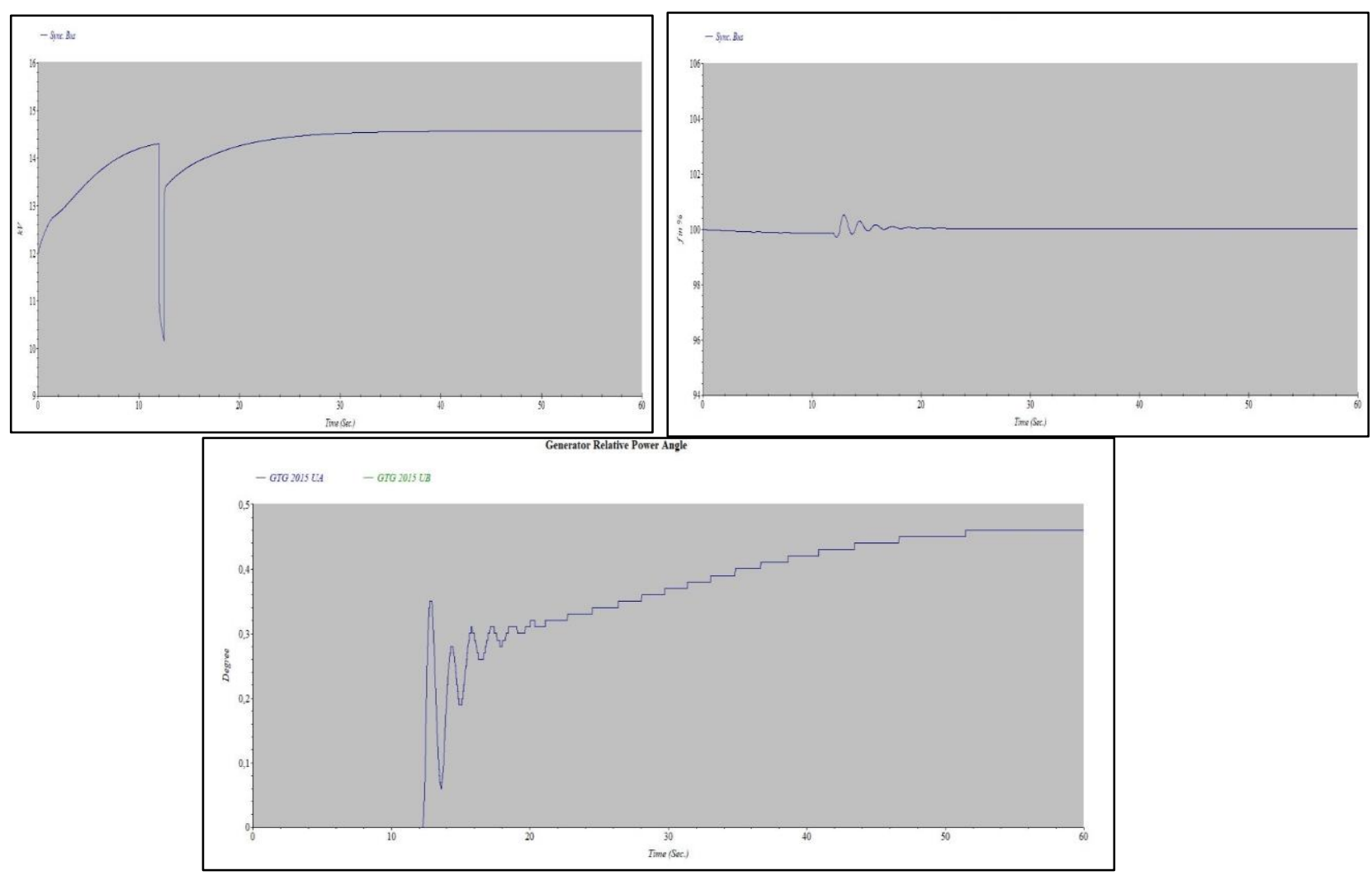

Gambar 7 Respon tegangan, frekuensi dan sudut rotor generator saat gangguan 3 fasa pada MCC29B2 setelah pengaktifan PSS

Pada saat terjadi gangguan setelah pengaktifan PSS, durasi waktu mencapai titik kestabilan adalah 5,4 detik dengan titik terendah sudut tegangan berada pada $3,5^{\circ}$ dan titik tertinggi sudut tegangan dinilai $1,95^{\circ}$ yang kemudian berosilasi sebelum mencapai posisi titik kestabilan. Sedangkan pada Gambar 8, yaitu respon tegangan bus saat gangguan diberikan, saat mencapai rise time menuju posisi kestabilan terjadi penurunan tegangan senilai $0,20 \mathrm{kV}$ pada waktu $(\mathrm{t})=15,521$ detik sebelum kembali menuju keadaan stabil.

Pada Tabel 6 dapat dilihat bahwa terjadi perbedaan ketika terjadi gangguan tanpa pengaktifan PSS dan setelah pengaktifan PSS. Saat diberikan gangguan 3 fasa pada salah satu bus, terjadi perbaikan nilai tegangan dan sudut rotor dengan durasi menuju kestabilan yang lebih baik dibandingkan tanpa menggunakan PSS. 

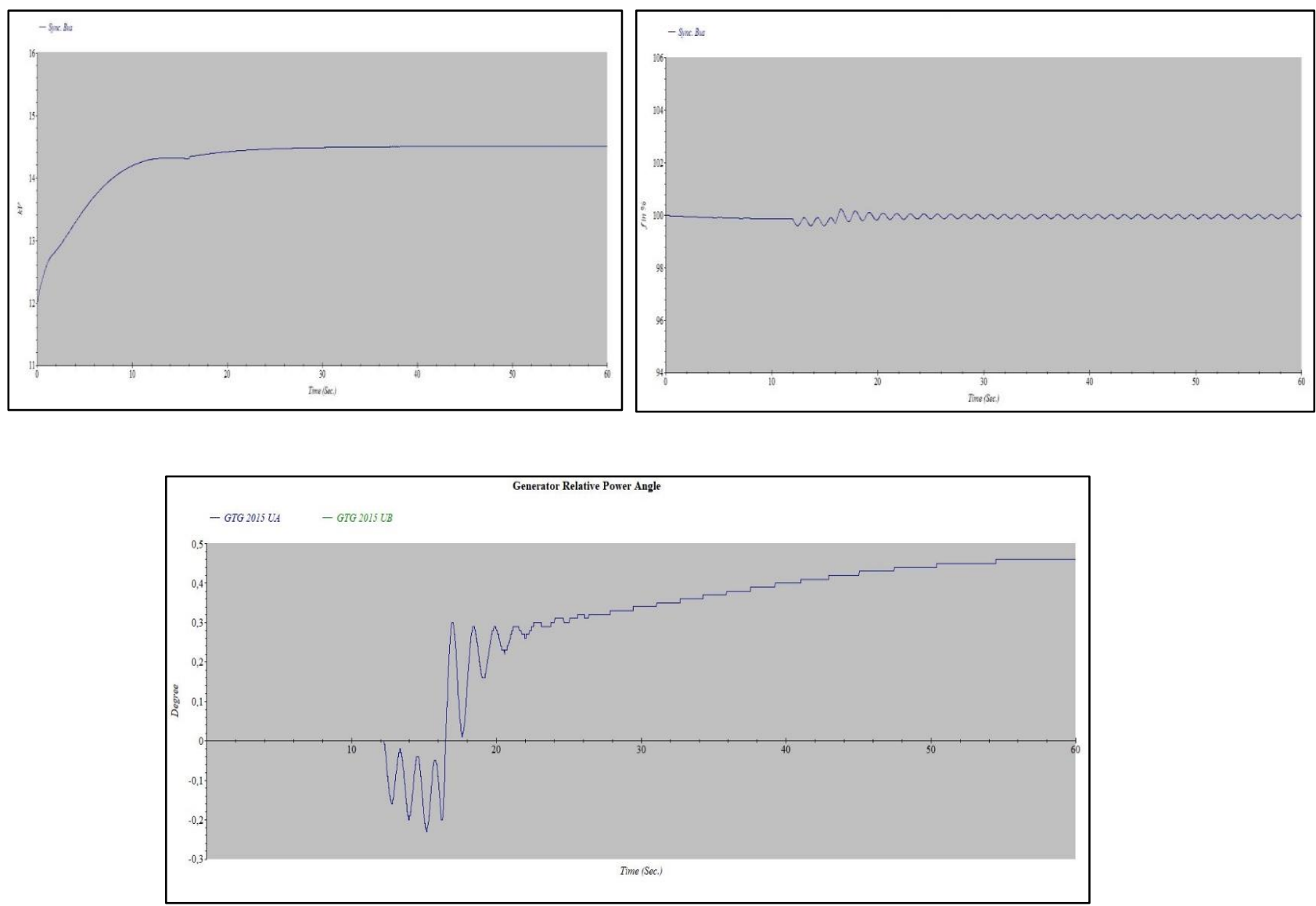

Gambar 8 Respon tegangan, frekuensi, dan sudut rotor generator saat gangguan 1 fasa pada MCC29B2 setelah pengaktifan PSS

Tabel 6 Hasil analisa sebelum pengaktifan dan setelah pengaktifan PSS

\begin{tabular}{|c|c|c|c|c|c|c|c|}
\hline \multirow[t]{2}{*}{ Lokasi } & \multirow{2}{*}{$\begin{array}{c}\text { Jenis } \\
\text { Gangguan }\end{array}$} & \multicolumn{3}{|c|}{ Tanpa PSS } & \multicolumn{3}{|c|}{ PSS } \\
\hline & & $f$ & $V$ & $\angle R$ & $f$ & $V$ & $\angle R$ \\
\hline \multirow[t]{2}{*}{ MCC29B1 } & $3 P F$ & $50,55 \mathrm{~Hz}$ & $6,95 \mathrm{kV}$ & 3,3 & $50,46 \mathrm{~Hz}$ & $6,8 \mathrm{kV}$ & 2,5 \\
\hline & $L G$ & $50,39 \mathrm{~Hz}$ & $6,91 \mathrm{kV}$ & 2,9 & $50,26 \mathrm{~Hz}$ & $6,89 \mathrm{kV}$ & 2,2 \\
\hline \multirow[t]{2}{*}{ MCC29B2 } & $3 P F$ & $50,57 \mathrm{~Hz}$ & $6,93 \mathrm{kV}$ & 3,25 & $50,43 \mathrm{~Hz}$ & $6,86 \mathrm{kV}$ & 2,49 \\
\hline & $L G$ & $50,41 \mathrm{~Hz}$ & $6,92 \mathrm{kV}$ & 2,97 & $50,24 \mathrm{~Hz}$ & $6,85 \mathrm{kV}$ & 2,18 \\
\hline
\end{tabular}

Jika ingin menambahkan kualitas daya listrik, maka dapat dilakukan dengan penggunaan Power System Stabilizer sebagai salah satu alternatif dalam perbaikan kestabilan transien.

\section{Kesimpulan}

Berdasarkan penelitian yang telah dilakukan, dapat ditarik beberapa kesimpulan sebagai berikut.

1. Berdasarkan simulasi load flow analysis pada sistem kelistrikan PT. Pertamina (Persero) Refinery Unit III Plaju, Sumatera Selatan, terdapat rugi-rugi daya sebesar 0,111 MW akibat variasi beban. Sedangkan untuk kondisi frekuensi, tegangan, dan sudut masih dalam ambang batas normal sesuai ANSI/IEEE C.37-106.

2. Kondisi sistem saat terjadi gangguan 3 fasa dan gangguan 1 fasa (line grounding) pada MCC29B1 serta MCC29B2 menunjukkan bahwa tegangan dan frekuensi masih dalam parameter batas normal ketika terjadi gangguan, baik dalam keadaan transien atau menuju titik kestabilan (steady state).

3. Perbaikan stabilitas transien sistem tenaga listrik, seperti pemakaian power system stabilizer berpengaruh kepada tegangan dan sudut rotor namun tidak terlalu berpengaruh terhadap frekuensi. 
Untuk peneliltian selanjutnya mengenai stabilitas transien sebaiknya dilakukan melakukan pengoptimalan nilai PSS dengan memberikan metode proportional integral atau metode fuzzy.

\section{Daftar Pustaka}

[1] F. Birol, "Oil 2019 Analysis and Forecast to 2024," 2019. [Online]. Available: https://www.iea.org/.

[2] I. Robandi, Desain Sistem Tenaga Modern Optimasi, Logika Fuzzy, dan Algoritma Genetika, Yogyakarta: ANDI , 2006.

[3] D. Marsudi, Pembangkitan Energi Listrik Edisi Kedua, Jakarta 13740: Erlangga, 2011.

[4] J. Duncan Glover, Power System Analysis \& Design, Fifth Edition ed., S. Maherishi, Ed., Stamford, Stamford: Global Engineering, 2008.

[5] N. Mohan, Electric Power System, D. Sayre, Ed., Wiley, 2004.

[6] P. Kundur, Power System Stability and Control, New York: EPRI Power System Engineering Series, 1994.

[7] Firdaus Ariansyah, " Analisa Kestabilan Transien dan Pelepasan Beban Pada Sistem Integrasi 33 KV PT. Pertamina RU IV Cilacap akibat Penambahan Beban RFCC dan PLBC," Jurnal Teknik ITS 5 (1), pp. B19-B23, 2016.

[8] J. William D Stevenson, Elements of Power System Analysis, U.S.A: McGraw-Hill Book Company Inc., New York, 1955.

[9] A. F. R, "Studi Proses Automatic Transfer Switch Emergency Diesel Generator 2016 - U di PT. Pertamina (Persero) Refinery Unit III Plaju - Sungai Gerong," Laporan Kerja Praktek Teknik Elektro - FT UNJA, pp. 27-31, 2018.

[10] Defariza, "Analisis Stablitas Transien dan Pelepasan Beban Sistem Kelistrikan di PT. Pertamina (Persero) Refinery Unit III Plaju - Sungai Gerong Palembang," Jurnal Teknik ITS, pp. 1-12, 2011.

[11] I Gede Yogi Aditya Dewantara, "Analisis stabilitas transient pada sistem $150 \mathrm{kV}$ bali dengan penambahan PLTU Celukan Bawang 150 kV," Electrical Engineering Itenas Malang, pp. 23-34, 2016.

[12] Harun, Nadjamuddin, Operasi Sistem Tenaga Listrik, Makassar, 2011.

[13] ANSI/IEEE, "ANSI/IEEE," IEEE Guide for Abnormal Frequency Protection for Power Generating Plants, pp. C.37-106, 1987.

[14] H. Saadat, "Power System Analysis," McGraw-Hill. International Edition, 1999.

[15] A. R. Priawan, "Analisis Stabilitas Transien Sistem Tenaga Listrik PT. Kebon Agung Malang," Universitas Brawijaya.

[16] C. W. Winanti, "Analisis Statis dan Dinamis Stabilitas Tegangan Sistem Tenaga Listrik CNOOC SES. Ltd," Universitas Indonesia, pp. 26-40, 2011.

[17] Wahyuni Martiningsih, "Perbaikan kestabilan dinamik pada sistem tenaga menggunakan kontrol gain AVR PSS," SETRUM- Volume 3 No 2, pp. 118-124, 2014.

[18] R. Masrul, "Analisis penggunaan Power System Stabilizer dalam perbaikan stabilitas dinamik sistem tenaga listrik multimesin," USU Repository, 2009.

[19] Direktorat Penyusunan APBN, Direktorat Jenderal Anggaran, "Informasi APBN 2019," Jakarta Pusat, 2018.

[20] C. Pranay Paria, "Power System Stability Analysis By Applying PSS in ETAP," pp. 18-20, 2018. 